\title{
The Study of Drug Use, Spirituality, Intimacy and Age as Determinants of Antisocial Behaviour among Youths
}

\author{
Agbo Christopher Okwudili1, Okoli Paul Chibuike2*, Ofojebe Chukwuma Philip ${ }^{3}$, \\ Chime Peter Ekpunobi², Akpoke Victor Okorieh", Ogundu Amara Grace ${ }^{4}$, Ezeme Mark Sunday² \\ ${ }^{1}$ Department of Psychology, University of Nigeria Nsukka, Enugu State, Nigeria \\ ${ }^{2}$ Department of Internal Medicine, ESUT College of Medicine, Enugu State University of Science and Technology, Enugu, Nigeria \\ ${ }^{3}$ Department of Psychology, Nnamdi Azikiwe University, Awka, Anambra State, Nigeria \\ ${ }^{4}$ Department of Psychology, Enugu State University of Science and Technology, Enugu, Nigeria \\ Email: *okolipd71@gmail.com
}

How to cite this paper: Okwudili, A.C., Chibuike, O.P., Philip, O.C., Ekpunobi, C.P., Okorieh, A.V., Grace, O.A. and Sunday, E.M. (2020) The Study of Drug Use, Spirituality, Intimacy and Age as Determinants of Antisocial Behaviour among Youths. Open Access Library Journal, 7: e6431.

https://doi.org/10.4236/oalib.1106431

Received: May 15, 2020

Accepted: June 27, 2020

Published: June 30, 2020

Copyright (๑) 2020 by author(s) and Open Access Library Inc.

This work is licensed under the Creative Commons Attribution International License (CC BY 4.0).

http://creativecommons.org/licenses/by/4.0/

\begin{abstract}
This study investigated drug use, spirituality, intimacy and age as determinants of antisocial behaviour among youths. Participants were four hundred and sixty eight (468) youths comprising (328) males and (140) females. Their ages ranged between $(9-25)$ years, with a mean age of 17 and standard deviation of 8.04. Cross sectional design was adopted. Four instruments were used for data collection: Antisocial Behaviour Scale, Simple Screening Instrument for Substance Abuse and Daily Spiritual Experience Scale validated in Nigeria by the present researcher and Emotional Intimacy Scale. Four hypotheses were tested. Step wise multiple regression analysis indicated that drug use $(\mathrm{p}<0.01)$. The result showed that spirituality, intimacy and age were all shown to be significant of antisocial behaviour; while spirituality, intimacy and age were shown to be negative determinants of antisocial behaviour. Marital status was positively significantly associated with antisocial behaviour, while educational qualification and religious denomination both had negative significant association with antisocial behaviour. Drug use was found to be positively significantly associated with antisocial behaviour while spirituality was positively significantly associated with antisocial behaviour. However, intimacy and age of participants were not significantly associated with antisocial behaviour. The implication of this study is there is urgent need to checkmate the rate of consumption/use of drug especially among the youths and more among the adolescence but more the source of supply.
\end{abstract}

\section{Subject Areas}

Criminology 


\section{Keywords}

Drug Use, Spirituality, Intimacy, Age, Antisocial Behaviour, Youths

\section{Introduction}

\subsection{Background}

Youth as a phase of life has been defined differently across time and according to different cultures. In Malaysia for instance, youth falls within the age group between 15 and 40 years [1]. The United Nations for statistics purposes however defines "youth" as those persons between the ages of 15 and 24years, without prejudice to other definitions by member states [2]. However, as stated by United Nations general assembly (2008), it is recognized that the meaning of the term youth varies in different societies around the world. In much of Sub-Saharan Africa, the term youth is associated with young people from 15 - 30 or even 35 years of age. Youth in Nigeria includes all members of the federal republic of Nigeria aged 18 - 15 years [3]. In Brazil, the term youth refers to people of both sexes from 15 or 18 to 25 years old [4].

Youths are expected future leaders. In a society where these would be future leaders engage in crimes, violence, and other delinquent and corrupt behaviours there may never be peace, progress and sustainable development. Peace is an important phenomenon, a condition the nation, the world and every individual needs. In the absence of peace there is the possibility of instability, insecurity, kidnapping, burglary, thurgery, assault, rape, street ganging, drug peddling and or abuse, and other vices [5]. In the contemporary Nigerian setting, the researcher observed that a lot of the youths exhibit dishonesty behaviours without any fear of apprehension. Both in rural and urban areas, the streets and residences are no longer safe, no matter how well fortified the may be. Street-smart-boys popularly known as "Area-boys" are found everywhere roaming the streets, harassing and extorting money from innocent people. Bank robbery, money laundering, involvement in theft popularly known as "419; kidnapping, car snatching, armed robbery, cultism, assaults, rape, violence, substance abuse, alcoholism, certificate racketing, vandalism, examination malpractices to mention but a few are challenges created by youths. Antisocial behaviours by youths appear to be symptoms of the social and moral decadence of the Nigerian society in general vis-à-vis other countries of the world.

This decay manifests itself in the form of various social vices and ills as indicated above and epitomized by corruption, indiscipline, moral laxity and many other ills in the society. Therefore, since youths in the society, who do not exist in a vacuum; observe this unhealthy social environment and the breakdown in societal values and norms; it is from what they observe and the signal they perceived that they, in order to achieve what they perceive as societal goals, emulate the behaviour of the adult society. In a society where persons who have achieved 
success through corruption are lauded, the signal sent to the youths is that corruption is an acceptable means of achieving success [6]. This of course, is reflected in the youths' antisocial behaviour. Moreover, the way youths of both gender make use of phones with applications in the society is very unbecoming. It has been suspected that a good number of youths are abusing phones as well as other electronic gadgets in the homes such as televisions and video sets. Phone applications appear to have become a means of communicating with delinquent peers as well as planning other antisocial activities. Some parents encourage the antisocial behaviours of the youths by the way they use phones to tell lies in the presence of young people.

Terrorism is an extreme side of antisocial behavoiurs, and this is prevalent in Nigeria. These violent practices have dominated the social landscape of the nation for decades. Antisocial behaviours are prevalent in both low and high places as such that it has necessitated the establishment of some structures by the Federal Government, such as Nigerian Drug Law Enforcement Agency (1989), Economic and Financial Crime Commission (ICPC) $29^{\text {th }}$ September, 2000 by Obansanjo Administration to check such negative behaviours. The prevailing atmosphere has given rise to some pondering questions as to what could have been the possible cause of youths and even young adults involvement in antisocial behaviours. The behaviour of young people is reflexively influenced by their surrounding environment [7], while a study on culture and youth sub culture indicated the emergence of new values and cultural patterns among young people which include individualism and materialism, religious orientation, the orientation, the orientation to foreign cultures, identity changes, communication behaviour and media habits, leisure activity, health habits and career aspirations [8].

The prediction and prevention of antisocial behaviour among youths is grounded on the knowledge of its cause. For some time, considerable efforts in both theory and research have contributed to explaining these causes. However, despite these advances, the causes, and the interplay of series of antisocial behaviours, with any human behaviour, remains a complex task. Besides, the complexity lies, in part, in the many factors that may influence the development of the antisocial behaviours, with any human behaviour within individuals. These factors cut across various domains (e.g. individual, family, peer affiliation, school and community neighborhood) and operate at multiple levels and different time periods. For instance, it has been reported that one of the risk factors for the youths antisocial behaviours is parenting style, especially harsh and inconsistent parenting [9]. As stated by some other researchers, other factors that are involved directly or indirectly include domestic violence, parental drug abuse, maternal depression, family poverty, parents with low education, stressed families and single parent status [10] [11].

Furthermore, studies have reported a significant relationship between high levels of parent warmth and lower levels of externalizing behaviour problems in youths. As observed by the researcher in many instances, many individuals, families, 
communities and others in various sectors have conflicting and diverging reasons for what causes antisocial behaviour among the youths. In Igbo Etiti L.G.A of Enugu State for instance, cases of variations as to what factors influence the occurrence of antisocial activities among youths abound among villagers. This problem which resulted over issues of sale of substances like alcoholic drinks-dry gin and hard drugs has caused some harm to the society. One of the most recent case scenarios observed by the researcher in one of the communities within the Local Government where the researcher works was a group of women who called themselves "Concerned women of the community". These women filed a case in one of the magistrate courts in their area against the other group of women that sell the dry gin in the community. The complainants hypothesized that when youths from the community consume this alcohol it creates enabling ground for various forms of antisocial behaviours. On the other side, the defendants maintained that alcohol and other drugs are not the cause of antisocial behaviours by youths rather; they attributed youths' antisocial behaviour to nature, not nurture as the complainants claimed.

What constitutes antisocial behaviour varies across time, context and culture. However, when one talks about behaviour that is antisocial, it refers to people who usually act in ways that are aggressive, intimidating, embarrassing or destructive which negatively impact on the quality of life of others [12]. Antisocial persons [13] are individuals who engage in pervasive pattern of disregard for and violation of the rights of others, occurring since age 15 years, as indicated by failure to conform to social norms with respect to lawful behaviour, as indicated by repeatedly performing acts that are grounds for arrest. Many of the youths have these personality traits and because of the prevailing situation of the country in terms of unemployment and economic problems, a good number of youth appear to behave in ways that are very disastrous to the people around. Antisocial individuals living as predators in life often can allure, manoeuvre and callously pull their way through, and as a result leaving behind them a wide range of people emotionally injured, dreams shattered, hopes destroyed and empty. Yet antisocial persons inconsiderately acquire what they want and behave in manner they prefer which may involve violating social norms and expectations without any qualms of conscience. In most of the urban areas of the country, government stopped the use of motor cycle "Okada" probably because it appears some youths use their motor cycles to commit certain form of atrocities fast and sometimes mask themselves under Okada business in the town and commit these social vices. Take for instance, in Enugu Metropolis in Enugu State of Nigeria; those who could not afford an alternative for "Okada", Tricycle (i.e. keke Napepe) have resorted to what the media called indiscriminate traffic regulation multiple taxation of premises and business areas as means of survival which rather seems like extorting money from the public.

The Crime and Disorder Act described antisocial behaviour as acting in ways that are likely to cause harassment or distress to one or more persons [14]. Prob- 
lems caused by antisocial behaviours by the youths add greatly to the cost of health and welfare services, reduces productivity, decreases the value of property, disrupts peace and a range of essential services, escalates insecurity and generally undermines the fabrics of societal development [15]. Individuals with antisocial personality tend to have long history of violating the rights of others [16]. More importantly, the lifelong pattern of antisocial behaviour is evident in the fact that young children who display antisocial behaviour are likely to continue these behaviours as they grow older [17]. It is suspected that many adults with antisocial personality disorder had conduct disorder as children. Lynam observed that the likelihood increases if the child had both conduct disorder and attention deficit/hyperactivity disorder. They often take chance and seek thrills with no concern for danger. They are easily bored and restless, unable to endure the tedium of routine or to persist at the day-to-day responsibilities of marriage or a job [18]. As a result, they tend to drift from one relationship to another and often are in low-status jobs [19]. They may engage in criminal activity impulsively, and 50 to 80 percent of youths in jail may be diagnosable with antisocial personality disorder [20]. Looking at most prisons are filled up by the youths. If this is true, then that also could explain the degree of social vices in the society.

A prominent pioneer in the study of people with antisocial personality, Hervey Cleckley, noted that, although these people often end up in prisons or dead, many of them become successful business people and professionals [21]. Cleckley suggested that the difference between these successful antisocial personalities and the other group who end up in jail or incarcerated severally is that the successful ones are better to maintain an outward appearance of being normal, perhaps because they have superior intelligence and can put on a "mask of sanity" and superficial social charm in order to achieve that goals. Some of the people have risen to a high position in the community, government and various sectors where they manipulate the youths especially in politics to achieve their aims with just a token. Others, who decide to remain in their business and professions, have metamorphosed to the extent of draining a country economically.

A number of factors seem to have relationship with antisocial behaviour and one of them is drug use. However, one reason for further investigation of this relationship is that substance use by young involved in juvenile justice system has increased in the past years [22] and uncertainty still persists as to whether drug use predisposes user to crime or vice versa [23]. Some earlier studies have shown that many children with conduct disorder become juvenile offenders [24] and they tend to get involved with drugs [25]. It appears that antisocial behaviours and drug use are associated over time, although there does not seem to be a clear progression from one to the other. In other words, while some researchers indicated that drug use causes or predicts antisocial behaviours among youths; other studies maintained that antisocial behaviours among young children predict drug use in the later part of their life. Studies have shown that behaviour 
problems and aggression at younger age predict later adolescent illicit substance use [26]. Moreover, another group of researchers also found that problem behaviours and aggression at younger age escalate the use of these substances overtime [27], and later diagnoses of substance abuse and dependence [28].

On the contrary, some studies suggest that early substance use predicts subsequent criminal behaviours in adolescent [29] [30] [31]. Alternatively, Goldstein claimed that the use of drugs may lead to antisocial activities either because the effects of these substances directly facilitate the development of such behaviour (psycho-pharmacological effects) or because the need to support substance use motivates antisocial behaviour for instrumental reasons (economic motivations) [32]. Some other studies supporting the above assertion showed that youth in juvenile court demonstrate that a majority of court involved adolescent have recently used illegal substances and are more likely to qualify for diagnosis of substance use disorder [33] [34] [35].

Considering various research findings by some other researchers, it appears that antisocial behaviour and drug use have certain relationship but the direction of the relation is what still remains uncertain. And another study on this issue found that substance use and antisocial behaviour fluctuate in similar patterns overtime, suggesting a reciprocal or sequential relationship, but no causal relationship has been proven; stressing further they hold that drug use appears to influence the behaviour of the consumer, and a group of researchers explained that certain drugs activate the ventual tegmental area and the nucleus accumbens, the areas of the brain that register reward and pleasure [36]. Some other researchers noted that many cocaine users and dependents started with heavy alcohol or marijuana use and then graduated to harder substances including cocaine [37] [38]. Most youths consume a lot of alcohol. In addition, a close observation shows that there is proliferation of joints in both urban and rural settings where a great deal of alcohol is consumed on daily bases. Unfortunately, observation shows that youths nowadays struggle for alcohol during ceremonies such as wedding, birthday, burial/funeral including other important occasions.

Drugs have effects on the individuals. Cocaine blocks the reuptake of dopamine into the transmitting neuron, causing dopamine to accumulate in the synapse, maintaining the pleasure feeling. Similarly, cocaine produces a sudden rush of intense euphoria, followed by great self-esteem, alertness, energy, and a general feeling of competence, creativity and social acceptability. Users do not feel drugged; instead, they feel they have become the people they always wanted to be [37]. The above characteristics of the drug seem to lure the youth into behaviours that are antisocial. However, sometimes they claim that it helps them to handle or cushion their awful challenges and experiences in their families and other undesirable experiences. Government efforts to forestall the use of hard drugs notwithstanding, the incessant use of alcohol and other hard drugs by the youths has remained a serious problem to the public [39]. As noted by Pudney 
the drug and alcohol abuse undermines perception, motivation, interferes with cognitive processes, and increases the urge for antisocial behaviours [23]. Furthermore, there is evidence that adolescent drug use is correlated with delinquency, teenage pregnancy and school misbehavior and drop out [40].

Spirituality is another important factor in the life of the youth. According to literature, this topic had been conducted among adolescent and young adult in developed countries like united state [41]. As such, important questions still remain in terms of establishing general effects and the nature of their relationship in developing countries that experience extremely high rate of violence, delinquency and other form of antisocial activities now applicable in Nigeria [42]. Accordingly, substantial evidence has been established that showed the protective role for spirituality against youth and young adults, involvement in antisocial behaviors, much less is known about the universality of the effect [43]. Worthington, defined it as a more general feeling of closeness and connectedness to the sacred. The researchers went further to classify spirituality into four dimension; the Religious spirituality (closeness and connectedness to the sacred defined by religion); humanistic spirituality (closeness and the connection to mankind); nature spirituality (closeness and connectedness to Nature); and Cosmos Spirituality (closeness and connectedness to the whole of creation) [44]. A more broad definition of spirituality was put forward by Mayer, who defined spirituality as "personal and private beliefs that transcend the material aspect of life and give a deep sense of wholeness, connectedness, and openness to the infinite". Accordingly, this conception spirituality includes: a) Belief in power beyond self, b) Behavior in relation to the infinite such as prayer, c) Meaning and purpose of life, d) Hope and optimism, e) Love and compassion, f) Moral ethical guidelines, g) Transcendental experiences [45].

Spirituality is more of an individual practice and has to do with having a sense of peace and purpose. It also relates to the process of developing beliefs around the meaning of life and connection with others [46]. There are research studies showing that spirituality is an important dimension in youth development. Unfortunately, despite the significance of this concept in youth development, a review of the available literature on children and youth showed that less than one percent examined issues on spirituality [47]. Scholars have also noted that religion and spirituality are relevant not only to youths in general but also to a high risk youth engaged in delinquency and antisocial behaviour. For instance, while few active Central American gang members are welcome in most religious communities, entrance into Evangelical Christian Community is one of the few viable options for gang members interested in terminating gang membership and reentering mainstream of the society [48]. Research in the United States has identified spirituality as important individual characteristics that can serve to buffer the adverse outcome of antisocial behaviours in youth [49]. While some research literature point to the inverse relationship between spirituality and a variety of antisocial behaviour [43]. Other studies have systematically examined the role of 
spirituality in the life's of youth with antisocial behavior and few, if any, among such youth in a developing society have been examined [50] [51]. Morris, indicated that when controlling for antisocial bonding and antisocial beliefs, spirituality was not uniformly protective against all manifestations of antisocial behaviours. In terms of severe antisocial behavior, spirituality was found to have protective influence against weapon carry and property destruction, but not associated with other more person forms of severe antisocial behaviour such as theft and hard drug selling [52]. The pattern may suggest that spirituality has a greater influence on delinquent behaviours that are either fundamentally passive in nature or are not directly related to other individuals [53].

The identification of spirituality as a protective factor against youth involvement in antisocial behaviours is certain in keeping with the bulk of the empirical research conducted in the United States [54]. On the other hand it appears that no studies were identified that explicitly examined such relationship between spirituality and antisocial behaviours in a typical African setting like Nigeria. In terms of severe antisocial behavior, spirituality was found to have protective influence against weapon carry and property destruction, but not associated with other more person forms of severe antisocial behaviour such as theft and hard drug selling. The pattern may suggest that spirituality has a greater influence on delinquent behaviours that are either fundamentally passive in nature or are not directly related to other individuals. A study using a national sample of American adolescent from the National Youth Survey, found that adolescent spirituality was associated with lower levels of adolescent antisocial affiliation and higher levels of prosocial beliefs, both which were, in turn, significantly associated with adolescent antisocial behaviours [54]. Stressing further on that, Salas-Wright, Vaughn, Hodge and Perrons, maintained that young people who are involved or showed elevated levels of spirituality tend to avoid the pitfalls of delinquency and related antisocial behaviours more often than their less spiritual counterparts [55]. These findings appear to confirm the previous finding that most young people view spiritual development as important part of their lives [56]. In the same way King and Boyatzis, similarly commented that adolescence may be particularly important time period to study spirituality in its developmental pattern. Unfortunately, despite the importance of spirituality in youth development, a review of the literature showed that less than one percent of the studies on children and youths had examined issues on spirituality and antisocial behaviour [57], adolescents spirituality and religion have been neglected in the developmental sciences. In addition, there is a huge gap in the study of spirituality in the clinical literature [58]. This may be due to the difficulty of its concrete objective definition. Spirituality as a concept is not clearly defined in science due to it high inconsistency as opposed to what the brain can fathom fully.

Another variable of interest in the study is intimacy. The word intimate comes from the Latin Word "Intima", signifying the deepest, most internal part of something. To be intimate is to uncover ones inside, to present oneself from the 
exposed and unprotected gut. In the act of intimacy we reveal our hearts and our viscera. One does this great anxiety and trembling, for the moment of opening to another on an intimate level, renders the person exquisitely vulnerable [59]. An interesting Japanese statement is that a man has three hearts. The first he keeps in his mouth for all to see. The second lay deep in his breast where only his close friends may go. The location of his third heart no one knows for he alone may see it. Intimacy is therefore the location of the third hearts, the act of being fully present with the other while being fully oneself [60]. Intimacy is the experience of emotional closeness which occurs when two people are able to be emotionally open with each other and reveal their true feelings, thoughts, fears and desires. This can only occur when both people are able to genuinely trust each other and feel able to take the risk of being vulnerable [61].

Intimacy is about being emotionally close to none's partner, being able to let one's guard down, and let the other know really how one feels. It is about being able to accept and share in one's partners' feelings, being there when he/she wants to let his or her defenses down [62]. Intimacy is an important part of human experience, with intimate relationship being the principal arena within which young people live out their emotional lives [63]. Downey had indicated that principles of sharing completely with one's partners the intellectual, spiritual, emotional, economic and social aspects of one's life cannot be psychologically overemphasized [64]. It seems that the prevalence of dating, coupling, courtship and marriage across cultures attest to the seemingly universal desire to be closely connected to another. Intimacy brings satisfaction and is often considered as the essential factors in adults/youths health, ability to adapt, happiness, and sense of meaning in life [62].

According to Selman, the ability to balance closeness and individuality heralds a mature form of friendship intimacy that typically does not emerge until adolescence [65]. Several features of intimacy characterize adolescent friendship [61]. Friends know one another's feelings and preferences, and support each other emotionally and materially. They discuss secrets, exchange ideas, and share feelings in a secure and accepting environment [66] [67]. Across adolescence, these characteristics of intimacy emerge as increasingly important constructs around which close friendships are organized [63]. Conceptually, adolescent friendship intimacy has converged on two themes: closeness and individuality. Closeness describes mutual empathy, love and felt security [68]. This closeness provides the impetus for self-disclosure, prompting discussions of personal matters such as sexuality, family problems, and money. Thus, closeness captures the interpersonal processes whereby friends share important feelings and information such as drug use [68]. The need for a close friend is especially strong during early adolescence. Studies have shown how this need for affiliation could be manifested in an increase of willingness to be similar to the other and in conformity to peer pressure [62]. In addition, through rewarding exchanges, friends strongly influence the thoughts, feelings, and behaviour of one another [69] [70]. In sum, the 
penchant for closeness between friends may be accompanied by conformity to or control of the friend.

Individuality, in contrast, describes the development of separate and distinct identities. Erickson elaborated on the interplay between intimacy and identity. Erickson claimed that a successful intimacy requires feelings of power and control allowing fusion without fear of ego toss. In such a relationship intimate partners are confident to express their own views. In addition, partners are respected by each other [71]. Though the need for close friends has been described as a hallmark of the developing adolescent [72], individuation also emerges gradually during adolescence, as children strive to distinguish themselves from both parents and peers [73]. Though individuation, adolescents express personal styles and create unique selves to be shared in intimate relationships. In a study of the nature of friendships across adolescent [65] suggested that maturity of relationship is evident in the interplay between intimacy and autonomy. At the lowest levels of intimacy, partners have a sense of shared experience where the feelings and actions of one are imitated by the other.

Conceptually, adolescent friendship intimacy has converged on two themes: closeness and individually. Closeness describes mutual empathy, love, and felt security [72]. This closeness provides the impetus for self-disclosure, prompting discussions of personal matters such as sexuality, family problems, and money. Thus, closeness captures the interpersonal processes whereby friends share important feelings and information such as drug use [74]. The need for a close friend is especially strong during early adolescence. Studies have shown how this need for affiliation could be manifested in an increase of willingness to be similar to the other and in conformity to peer pressure [62]. In addition, through rewarding exchanges, friends strongly influence the thoughts, feelings and behavior of one another [69]. In summation, the fondness for the closeness between friends may be accompanied by conformity to or control of the friend. Yet, intimacy bothers on balancing needs and respecting individually as well as different views. The approach in which this tension is resolved reflects the maturity of a relationship.

There are sex differences in friendship intimacy and that adolescent females are reportedly closer and more inclined to self-disclosure than males [72]. Furthermore, it has been explained that males tend to express themselves through separateness, characterizing friendships in terms of shared activities, whereas females perceive relatedness, emphasizing mutual closeness and reciprocity in friendships. However, it is observed that former studies have not explicitly compared how adolescent males and females balance closeness and individuality within their close friendships. It would also be reasonable to assume that girls, for whom it is important to secure connectedness, will be more inclined to give up individuality. Boys, in contrast, will tend to control their peers and insist on their individuality [62]. Few studies have examined individual differences in adolescent relationship intimacy. Research adapting a relationship typology from sys- 
tem theory identified two types of friendships: interdependent and disengaged [75] [76]. Interdependent friends were found to be connected by an emotional bond-it was important for them to cooperate. However, this closeness neither involved total dependence nor precluded separateness in thinking and acting. In the disengaged type, close friends probably were unable to integrate differing opinions and therefore ended up working separately and insisting on their individuality. It is suggested that the distinction between the two types of friendship might further be demonstrated by their concepts of intimacy. For adolescents belonging to the interdependent type of friendship, this concept might reveal a better balance between closeness and individuality, whereas for disengaged this concept might reflect less respect for their close friend's individuality.

The present investigation is based on a model of adolescent friendship intimacy that considers individual differences in the quality of close relationships [77]. From this perspective, friendship intimacy entails disclosure, and commitment, as well as tendency to impose control or to conform to the other in order to secure the friendship. In addition, intimacy also entails of individuality like respect for the friend an ability to cope with differing views. The maturity of the relationship reflects a balance of closeness and individuality. Across adolescence, more mature relationships should develop as children are better able to integrate the competing demands of friendship. Individual differences are expected, however, as some adolescents lag behind others in to intimacy, especially with respect to individuality and expressions of closeness. A close observation of what happens among young couples newly married and wedded in both developed and the developing countries like Nigeria is something to worry about. Take for instance, in many denominational churches especially in the catholic diocese of Abakaliki, Awka, Awgu, Enugu and Nsukka, cases of divorce are very rampant. From the foregoing; it appears intimacy is in the centre of whatever may be the cause of the problem. It could be as a result of presence of intimacy or lack of it between the young couples, considering what usually comes up in the marriage tribunal of the respective dioceses.

These days one wonders whether the series of conflicts or dysfunctional families observed among couples have some relationship from their biological parents or guardians or the age of respective couple. The fourth independent variable in the study is age. In most societies, age is a major dimension of social organization. The school system, for instance, is carefully arranged around the student's age, and the behaviour of all students is clearly differentiated from the behaviour of adult teachers. Similarly, to a greater or lesser extent, families, corporations, even whole communities are organized by age. Further, they observed that age plays an important part on how people relate to one another across the whole range of everyday experience, and also forms a major touchstone by which range of everyday experience, and also forms a major touchstone by which individuals organize and interpret their own lives. A close observation shows that different societies define age in different ways. However a society like Nigeria de- 
fines age at least period; childhood, adulthood and old age. In modern America as well as in Nigeria, people are considered adults in the political system when they reach 18years and are given the right to vote, but they are not adult in the family system until they marry and take on the responsibilities of parenthood [78]. Considering what usually happen in the society these days in terms of antisocial activities and the age-brackets that are mostly involved, it appears youths are the majority. On the other side, one cannot under estimate one's age in terms of getting involved in antisocial activities as close observation shows that sometimes a child of a very young age commits antisocial activities that are unbelievable to people around. In the same way, some old adults are not left out in the scene. Take for instance; the people who contribute to the sufferings of Nigerians politically and economically are not only the youths, even though youths seem to be mostly involved.

\subsection{Statement of the Problem}

The fact that some previous researchers have antisocial behavior is established already in the life of some individuals and could not be attributed to the effects of drugs, it is however important to note that antisocial behavior still remains a global problem that greatly affects the social, physical and economic development of individuals and families within the society. In all, one cannot but continue to wonder why it is the youths-the leaders of tomorrow that appear to be mostly involved in this ugly situation. Besides, people still have varying opinions over what contribute to escalate or exacerbate the occurrence of antisocial behaviors among youths. For instance, the issue of drug use has become controversial as to which causes the other, some said drug use predicts antisocial behaviors; while still others say it is in the opposite. Moreover, as our country Nigeria records thousands of churches cum mosque, as well as other spiritual centers, close observation shows that youths usually form a reasonable percentage of the total congregation in almost all the churches irrespective of the denominations. It appears to be a common assertion that church attendance is associated with spirituality in a positive way. The confusion that arises remains that those youths that are usually found in churches and engage in various church activities are being suspected of being involved in many antisocial activities in the societies.

Furthermore, intimacy is positive phenomenon especially among members of families particularly among couples. These days, taking into cognizance of what is going on in many young families in terms of family instability and numerous cases of divorce, one wonders whether intimacy which is expected to be the bedrock of every family has become the accusing finger. More still, some people are in prison today not necessarily for an offence they committed but because they are intimacy related to one culprit who eventually ropes them in. on the reverse side, other youths that are good in terms of their characters, change abruptly probably because of their intimacy with some peers that are morally bad.

Besides, the age of getting involved in antisocial activities has been controver- 
sial among some researcher [79]. In Nigeria today for formation of about six different tribunals to handle behaviours that are antisocial are not limited to youths. Considering the trends of things in the society, especially as it concerns the economy of the country, one wonders if youths as a group, are the major problem. Much as curious as this study could be, as other scientific studies, this study is interested in exploring the contributions of drug use, spirituality, intimacy and age in antisocial behaviours among youths. Based on the above premise, this study like other scientific studies; aims at investigating contributions of drug use, spirituality, intimacy and age in antisocial behaviours of youths.

From the forgoing, the researcher examined certain research questions that guide the study. Hence the study specifically addressed the following problems.

1) Will drug use be a significant determinant of antisocial behavior among the youths?

2) Will spirituality be a significant determinant of antisocial behavior among the youths?

3) Will intimacy be a significant determinant of antisocial behavior among the youths?

4) Will age be a significant determinant of antisocial behavior among the youths?

\subsection{Purpose of the Study}

The study general purpose of this study is to examine drug use, spirituality, intimacy and age as determinants of antisocial behaviour among youths. But specifically to investigate:

a) If drug use among youths will determine antisocial behavior;

b) If spirituality will determine antisocial behavior of youths;

c) If intimacy will determine antisocial behavior of youths;

d) If age will determine antisocial behavior of youths.

\subsection{Operational Definition of Terms}

Antisocial Behaviour: This is defined as acting in a manner that is likely to cause harassment, alarm or distress to one or more persons as measured by the Antisocial Behaviour Scale [80].

Drug use: This refers to consumption of any natural or synthesized product that effects or that usually changes perception, thought, memory, emotion, reasoning and general behavior of the person as measured by the Simple Screening Instrument for Substance abuse (SSISA), Self-Administered Form [81].

Spirituality: A general feeling of closeness and connectedness to the sacred. This is measured using the Daily spirituality Experience Scale [82].

Intimacy: Refers to a person's ability to form close relationships with significant others as measured by the Emotional Intimacy Scale [83].

Age: Age in this study is operationalized as the condition of being a youth (12 -35 years). 


\section{Method}

\subsection{Participants}

Four hundred and sixty eight (468) youths comprising males and females of unequal sample size were randomly selected using random sampling techniques as it is the effective way of obtaining a representative sample of the population. The participants were drawn from five Towns within Igbo Ektiti Local Government Area, Enugu State. The Town included: Aku, Ukehe, Ohodo, Ozalla and Ekwegbe. Participants' ages ranged from 12 years to 35 years with a mean age of 23.5years; standard deviation of 8.01 out of the participants that participated in the study; three hundred and twenty eight (328) reported that they are male while one hundred and forty (140) were female; one hundred and seventy (170) were married, while two hundred and ninety eighty (298) were single; only 1 (one) participant reported holding First School Leaving Certificate (FSCL), two hundred and fifty three (253) has SSCE, forty six (46) hold NCE/OND while one hundred and sixty eight (168) hold HND/Degree; three hundred and thirty one (331) belong to Catholic religious denomination, twenty (26) belong to Traditional religious denomination, forty seven (47) belong to Anglican religious denomination while sixty four (64) belong to Pentecostal religious denomination. Fifty four (54) were Trader/Business people. Two hundred and fifty four (254) were Students, thirty five (35) were Civil servants, Eighty eight (88) were Farmers, and thirty five (35) were drivers while four (4) participants who have no job.

\subsection{Instrument}

Four instruments were used in this study. They are Antisocial Behaviour Scale, Drug Use Scale, Spirituality Scale, and Emotional Intimacy Scale.

Antisocial Behaviour Scale (ABS): The ABS is a 29-item scale developed by Immanuel [80] to assess antisocial/psychopathic behaviour. It includes behaviours such as fighting, stealing, killing, violence, aggression, bullying, as well as callousness, lack of guilt feeling even when one has done wrong, coldness, impulsivity, and so on. The ABS was validated on youths 12 years and above. The ABS has two factors; Factor 1-Callousness-16 items. These include item numbers 2, 8, 10, 12, 14, 19 - 29. Factor 2-Anti-social behaviour-13 items. These include numbers $1,3,5,6,7,9,11,13,15,16,17,18$. Thus, the ABS has construct validity. The internal consistency of the ABS was established with Cronbach's alpha $r=$ 82 , and split-half reliability of $r=70$, suggesting that the ABS is a valid and reliable instrument for assessing antisocial/psychopathic behaviour. The response options and scoring for the ABS are Always $=5$, Almost Always $=4$, Sometimes $=3$, rarely $=2$ and Never $=1$.

Simple Screening Instrument for Substance Abuse (SSISA): The Simple Screening instrument for Substance Abuse (SSISA) was developed by the Center for Substance Abuse Treatment (1994). It is a 16-item scale, although only 14 items are scored so that scores can range from 0 to 14 . These 14 items are selected from existing alcohol and drug abuse screening tools. A score of 4 or greater has 
become the established cutoff point for warranting a referral for a full assessment. Since its publication in 1994 the SSISA has been widely used as its reliability and validity investigated. Peters, Greenbaum, Steinberg, Cartar, Ortiz and Valle reported on a national survey of correctional treatment for COD. Reviewing 20 COD treatment programs in correctional settings from 13 States, the SSISA was identified as among the most common screening instruments used. Peters et al. (2000) found the SSISA to be effective in identifying substance dependent Inmates, and the SSISA demonstrated high sensitivity (92.6\% for alcohol or drug dependence disorder, $87.0 \%$ for alcohol or drug abuse or dependence disorder) and excellent test-retest Reliability (0.97). They found the SSISA a reliable substance abuse screening instrument among adolescent medical patients [84]. The researcher in a pilot study administered the SSISA to 124 youths from Igbo Eze South Local Government Area, Enugu State. The item analysis yielded Cronbach's alpha $=0.86$; split-reliability $=0.90$.

\subsection{Daily Spiritual Experience Scale}

The DSES is a self-report measure consisting of sixteen items. The instrument was designed to measure every day, spiritual experiences and how they are a part of the individual's daily life. Sample items from the scale include, "I feel God's presence". "I feel comfort in my religion or spiritually". And "I feel a selfless caring for others". The first 15 items of DSES are measured on a 6-point Likert-type scale: many times a day, every day, most days, some days, once in a while, and never or almost never. Item 16 is measured on a 4-point scale: not close at all, somewhat close, very close, as close as possible. Lower scores on the scale indicate more frequent daily spiritual experience. Evidence of validity was established for the DSES through in depth interviews and focus groups discussion with individuals from a variety of religious backgrounds and through reviewing other scales and theological, spiritual and religious writings. Correlations among the items of the DSES were moderate to high ranging from $r=60$ to $r=80$. Internal consistency reliability estimates for the scores from the normative sample were high, $r=94$. Several exploratory factor analyses (EFA) were conducted for the DSES. First, an exploratory principal factor analyses was performed to examine the dimensionality of the DSES. The item set was non dimensional for this sample set. Next, an EFA with oblique rotation was conducted. Nearly all items loaded highly on the first factor, with loadings ranging from 0.69 to 93 . Two loaded at 0.33 and 0.27 , but only accounted for $8 \%$ of explained variance. Two additional EFAs were performed with the dichotomization of items at two different points. The second dichotomization-the combination of never, once in a while, and some days versus most days to many times a day-yielding results more similar to those with continuous response format and performed more consistently. The internal consistency for this version of the scale was 0.93 [85].

Emotional Intimacy Scale: The emotional intimacy scale (ESL) is a 14-item scale developed by Onyeizugbo. The EIS is a measure of emotional intimacy. This involves tendency to sharing personal information with one's partner, valuing, 
emotional support, respect, spending time with one's partner, listening and general feeling of being-at-home with each other. The EIS can be used to assess the quality/level of intimacy in married couple, as well as close friends. The EIS has two factors. The alpha for Factor 1 (emotional vacuum) $=0.88$. Alpha for factors 2 (Emotional support) $=0.80$. The EIS has Cronbach's alpha of 0.89 for the full scale. Thus, the EIS is a reliable and valid scale for measuring the construct emotional intimacy [83].

\section{Procedure}

The researcher with a letter of identification from the Department obtained permission from the Town Leaders of the towns that were randomly selected to be used in the study. The researcher approached the participants at different sites where they are easily and readily available within the towns for the study, such as motor parks, town hall/squares, etc. At each of the setting the researcher introduced himself and explained the reasons for the study, and having those who willingly consented to participate signed the consent form, before administering the questionnaires. Participants were equally assured that their response will be treated with confidentiality. The questionnaires were administered to the participants with the help of research assistants. The questionnaires were collected back after the participants had filled them. One hundred (100) copies of questionnaires were distributed in each town, a total of five hundred (500) copies of questionnaires. After the questionnaires were collected back, they were cross checked. Out of five hundred (500) copies of questionnaires distributed, only four hundred and seventy five (475) copies of questionnaires were returned (95\%). After cross checking the questionnaires for irregularities, only four hundred and sixty eight (468) copies of questionnaires (93.6\%) were found to be properly filled and were used for data analysis.

\subsection{Design/Statistics}

This is a cross-sectional survey design and Multiple Regressions was employed for the data analyses.

\subsection{Results}

The data obtained from respondents were analyzed by computing the correlations among the study variables. Thereafter, to test the hypotheses, Step Wise Multiple Regression was conducted in which Antisocial Behavior was the dependent variable. The variables were entered into the equation, demographic variables (gender, marital status, highest educational qualification, religious denomination, and occupation) were entered in order to control for the likely impact they may have on antisocial behaviour. Drug use was entered in step 2 of the equation; the second independent variable-spirituality was entered in step 3 , while intimacy-the third was entered in step four. Lastly, age-the last independent variable was entered in step 5 of the equation all in a bid to test the extent to which they serve as determinants of antisocial behaviour. 
Correlations in Table 1 below showed that among all the demographic variables, only occupation was not significantly related with antisocial behaviour. Hence, gender $(r=0.11, p<0.01)$, and marital status $(r=0.12, p<0.01)$ were positively significantly associated with antisocial behaviour, while educational qualification $(\mathrm{r}=-21, \mathrm{p}<0.001)$ and religious denomination $(\mathrm{r}=-0.13, \mathrm{p}<$ 0.01 ) both had negative significant association with antisocial behaviour. The negative correlation showed that people with lower educational qualification are more likely to exhibit antisocial behaviour, than people with higher educational qualification. For religious denomination, the negative correlation indicated that people who go to many churches without observing or practicing what is taught exhibit more antisocial behaviour. Amongst the major variables studied, intimacy and age of participants were not significantly associated with antisocial behavior. But drug use $(r=-12, \mathrm{p}<0.01)$ was found to be negatively significantly associated with antisocial behaviour. The association implies that the more an individual uses drug, the more antisocial behaviour the person will manifest. Notwithstanding, spirituality $(\mathrm{r}=0.42, \mathrm{p}<0.001)$ was negatively significantly associated with antisocial behaviour. Thus, the more spirituality one gets the less antisocial behaviour the person will manifest.

Controlling for the demographic variables (gender, marital status, highest educational qualification, religious denomination and occupation) entered in step 1, the first major independent variable studies-drug use was entered in step 2 of the equation. Result of regression analysis (Table 2) showed that it accounted for statistically significant $8 \%$ variance as a determinant of antisocial behaviour $\left(\Delta \mathrm{R}^{2}=\right.$ $0.08, \mathrm{p}<0.01$ ), however making unique and statistically significant negative contribution in determining antisocial behaviour $(\beta=-0.01, \mathrm{p}<0.01)$. The inclusion of spirituality in step 3 of the equation was able to account for statistically significant $13 \%$ variance in determining antisocial behaviour $\left(\Delta \mathrm{R}^{2}=0.13, \mathrm{p}<0.001\right)$,

Table 1. Table of correlation across variables of interest.

\begin{tabular}{lccccccccc}
\hline Variable & 1 & 2 & 3 & 4 & 5 & 6 & 7 & 8 & 9 \\
\hline 1) Anti-Social & - & & & & & & & \\
2) Gender & $11^{* *}$ & & & & & & & & \\
3) Marital Stat & $0.12^{* *}$ & & $0.23^{* *}$ \\
4) Edu-Quali & & & & & & & \\
5) Relig_Deno \\
6) Occupation \\
7) Drug_Use \\
8) Spirituality \\
9) Intimacy \\
10) Age
\end{tabular}


Table 2. Hierarchical multiple regression predicting antisocial behaviour from drug use, spirituality, intimacy and age.

\begin{tabular}{|c|c|c|c|c|c|c|}
\hline & $\mathbf{R}$ & $\mathbf{R}^{2}$ & $\mathrm{R} \Delta^{2}$ & B & $\operatorname{Beta}(\beta)$ & $\mathrm{T}$ \\
\hline \multicolumn{7}{|l|}{ Step 1} \\
\hline \multicolumn{7}{|l|}{ Gender } \\
\hline \multicolumn{7}{|l|}{ Marital status } \\
\hline \multicolumn{7}{|l|}{ Education } \\
\hline \multicolumn{7}{|l|}{ Qualification } \\
\hline \multicolumn{7}{|l|}{ Religious } \\
\hline \multicolumn{7}{|c|}{ Denomination } \\
\hline \multicolumn{7}{|l|}{ Occupation } \\
\hline \multicolumn{7}{|l|}{ Step 2} \\
\hline Drug Use & $0.25^{\star *}$ & $0.05^{\star *}$ & $0.08^{\star *}$ & -0.07 & $-0.01^{\star *}$ & -26 \\
\hline \multicolumn{7}{|l|}{ Step 3} \\
\hline Spirituality & $42^{\star * *}$ & $18^{* * *}$ & $13^{* * *}$ & 0.70 & $0.37^{\star * *}$ & 8.38 \\
\hline \multicolumn{7}{|l|}{ Step 4} \\
\hline Intimacy & $0.46^{* * *}$ & $0.22^{* * *}$ & $0.04^{* * *}$ & -0.39 & $-0.22^{\star * *}$ & -4.76 \\
\hline \multicolumn{7}{|l|}{ Step 5} \\
\hline Age & $0.50^{* *}$ & $0.25^{* * *}$ & $0.03^{* * *}$ & 0.63 & $0.22^{* * *}$ & 4.45 \\
\hline
\end{tabular}

making unique and statistically significant positive contributions in determining antisocial behaviour $(\beta=0.37, \mathrm{p}<0.001)$. The entry of intimacy in step 4 of the equation added statistically significant positive $4 \%$ variance as determinants of antisocial behaviour $\left(\Delta \mathrm{R}^{2}=0.04, \mathrm{p}<0.001\right)$, making statistically significant negative contribution in determining antisocial behaviour $(\beta=-0.22, \mathrm{p}<0.001)$. Finally, age was entered in step 5 of the equation. It only added $3 \%$ variance as a determinant of antisocial behaviour $\left(\Delta \mathrm{R}^{2}=0.03, \mathrm{p}<0.001\right)$. However, it made a unique and statistically significant positive contributions in determining antisocial behaviour $(\beta=0.22, \mathrm{p}<0.001)$.

\subsection{Summary of Findings}

1) In the correlations table, only gender $(\mathrm{r}=0.11, \mathrm{p}<0.01)$, and marital status $(\mathrm{r}$ $=0.12, \mathrm{p}<0.01)$ were positively significantly associated with antisocial behaviour, while educational qualification $(\mathrm{r}=-21, \mathrm{p}<0.001)$ and religious denomination $(r=-0.13, p<0.01)$ both had negative significant association with antisocial behaviour. Occupation had non-significant negative association with antisocial behaviour.

2) Drug use $(r=-0.25, p<0.01)$ was found to be positively significantly associated with antisocial behaviour. While spirituality $(\mathrm{r}=0.42, \mathrm{p}<0.001)$ was positively significantly associated with antisocial behaviour. However, intimacy and age of participants were not significantly associated with antisocial behaviour. 
3) Drug use accounted for statistically significant $8 \%$ variance as a determinant of antisocial behaviour $(\Delta \mathrm{R}=0.08, \mathrm{p}<0.01)$, however making unique and statistically significant negative contribution in determining antisocial behaviour $(\beta=-0.01, \mathrm{p}<0.01)$.

4) Spirituality account for statistically significant $13 \%$ variance in determining antisocial behaviour $\left(\Delta \mathrm{R}^{2}=0.13, \mathrm{p}<0.001\right)$, making unique and statistically significant positive contribution in determining antisocial behaviour $(\beta=0.37, \mathrm{p}<$ $0.001)$.

5) Intimacy added statistically significant positive $4 \%$ variance as determinants of antisocial $\left(\Delta \mathrm{R}^{2}=0.04, \mathrm{p}<0.001\right)$, making statistically significant negative contribution in determining antisocial behaviour $(\beta=-22, \mathrm{p}<0.001)$.

6 ) Finally, age only added $3 \%$ variance as a determinant of antisocial behaviour $\left(\Delta \mathrm{R}^{2}=0.03, \mathrm{p}<0.001\right)$. However, it made a unique and statistically significant positive contributions in determining antisocial behaviour $(\beta=0.22, \mathrm{p}<0.001)$.

7) From the study, drug use was found to be positively and significantly associated with antisocial behaviour, $(\mathrm{r}=25, \mathrm{p}<0.01)$. The association implies that the more an individual use drugs, the more likely the person will engage in antisocial behaviours, leading to negative consequences such as robbery, kidnapping, fighting, arson, killing, raping. Drug use accounted for about seventy (70) percent involvement in antisocial; activities among the participants in the study.

8) Moreover. Spirituality was seen to be negatively and also significantly associated with antisocial behaviour in the study $\left(\mathrm{r}=0.42, \mathrm{r}^{2}=0.18, \mathrm{p}<0.01\right)$. This means that the more spiritual one becomes, the less likely that the person will engage in antisocial behaviour. From the findings in the study, a good number and percentage of people involved in antisocial behaviour have little or no spiritual commitment.

9) The third independent variable of the study (intimacy) was found to be negatively associated with antisocial behaviour $\left(\mathrm{r}=0.46, \mathrm{r}^{2}=0.22, \mathrm{p}<0.001\right)$. This implies that intimacy, thought negatively associated with antisocial behaviours, it has no significant association with antisocial behaviour.

10) Finally, age the fourth variable of the study, was found to be negatively associated with antisocial behaviours $\left(r=0.50, \mathrm{r}^{2}=0.25, \mathrm{p}<0.01\right)$. Age has negative and significant contributions in determining antisocial behaviours as found from the study. Drug use was found to be positively significantly associated with antisocial behaviour among youths. The percentage accounting for antisocial behaviour is about 70 percent from the study. Spirituality accounted for about 15 percent, percentage in antisocial behaviour among the participants while intimacy and age were 3 and 12 percent respectively.

\section{Discussion}

\subsection{Hypothesis of the Study}

This study examined drug use, spirituality, intimacy and age as determinants of antisocial behaviour among youths. The finding of the study showed that drug use is a significant determinant of antisocial behaviour among youths. The first 
hypothesis which stated that drug use will be a significant determinant of antisocial behaviour among youths was confirmed. This finding is consistent with previous empirical research findings [86] [87] [88] [89] indicating that youths with antisocial behaviour are significantly higher among users of Marijuana, cocaine, or crack than among youths who were not drug users. Similarly, studies have shown that drinking alcohol was a strong predator of an increase in criminal activity (graffiti, vandalism, or shoplifting) in the following year. They maintained that even after adjusting for other factors, someone who drinks once or twice a week is six times more likely to increase their criminal activity over the next year, compared to non-drinker. As found by Word Health Organization a sample of youth population in one of the developing countries, has showmen that drugs use highly correlated with antisocial behaviour. Studies has shown that substance use in one of the most consistent indicators of continued serious antisocial behaviours this however implies that drug use strongly influences antisocial behaviour especially amongst youths [90] [91]. A possible reason for drug use being significant predictor of antisocial behaviour could be because of control influence that drug usually have on users. Just like a musician under emotionality can perform extraordinary, so also do individuals under the influence of drug engage in certain behaviours (part of which is antisocial) as a result of control effect that goes with drug use.

The second hypothesis that spirituality will be a significant determinant of antisocial behaviour was confirmed by the result of the study indicating that spirituality actually serves as determinant of antisocial behaviour. The finding is consistent with relatively recent study [92] [93] [94] [95] showing that high level of spirituality is consistently associated with reduced risk behaviours such as smoking, alcohol use, truancy, sexual activity, marijuana and or cocaine uses and depression. That high level of spirituality is significantly correlated with positive behaviours. The finding of the study also supported other previous studies such as [54] [96] [97] [98] [99] reporting that measure of spirituality such as church attendance and importance of religious faith are inversely related to juvenile drug, alcohol, tobacco use delinquency; that spirituality is inversely related to the thoughts of suicide, attempted suicide and actual suicide among youths in the developing countries. That spirituality is negatively correlated with delinquent behaviours such as theft, vandalism, violence and substance abuse implying that people who have lower spirituality engages more in antisocial behaviour. The finding is inconsistent with the findings of Benda and Corwyn, which showed that spirituality rather than church attendance is significantly related to crime and the former remains a significant predictor event if it is analyzed simultaneously, with the strongest predictor observed in the literature [100]. The finding supported the assumption of Frankl theories of spirituality that spirituality is part of quality of life. According to him when a person fails to find meaning in life, and a state of vacuum is present, he or she is confronted by existential frustration which is characterized by feeling of boredom and antisocial tendencies. 
The third hypothesis stated that intimacy will be a significant determinant of antisocial behaviour among youths. This was confirmed in a negative form by the finding of the study as it indicated that people who lack intimacy exhibited antisocial behaviour unlike individuals with intimate support. This finding is consistent with relatively extant finding by Rachael, Laura and Mikayla reporting that multilevel modeling showed those children who had negative peer experiences in which no one intervened had more negative and less positive mood. And that for negative mood this result was attenuated if the child had a friend who was generally helpful [101]. Hence, the results demonstrate the positive role of bystanders during NPEs and highlight the protective role of high-quality friendships. The finding is also consistent with other previous studies such as [102] [103] [104] [105] who found that deficiencies in communication with friends or confrontation experiences and feelings of alienation are related to some forms of maladaptive behaviour. For both boys and girls, relations victimization was found to predict higher levels of internalizing behaviours directly and through partial mediation by greater conflict and weaker feelings of help within adolescent's best friendships. Increased conflict also partial mediated the association between relational victimization and higher levels of externalizing behaviours. Together, the results provided supports for the significance of broader peer group functioning on both dyadic relationships and individual functioning. In line with the findings, it recommended that the possibility to confer personal problems and the preoccupations to friends seems beneficial for the acquisition of adaptive behaviour. According to Bowlby in attachment theory, human beings are born with an innate psychobiological system (the attachment behavior system) that motivates them to seek proximity to significant others (attachment figures) in times of need [106]. The attachment behavioral system serves to maintain or achieve closer proximity to the attachment figure [107]. The proximity seeking to the attachment figure at the moment of threat turns into a set-goal of the attachment behavioral system. The attachment theory explains how much the parent's relationship with the child influences development.

The last hypothesis which postulated that age will be a significant determinant of antisocial behaviour among youths was therefore confirmed. Hence, age was found to be a positive determinant of antisocial behaviour among youths. The finding is in line with previous findings example [88] [89] [107]-[112] which indicated that antisocial behaviours peak sharply at about age 17 and drop precipitously on young adulthood. That the majority of criminal offends are teenagers, by the early $20 \mathrm{~s}$, the number of active offenders decrease by over $50 \%$ and by age 28 , almost $85 \%$ of the former delinquents desist from offending. Interestingly, results from these studies showed that over 80 percent of youths who used alcohol and cigarettes were between the ages of 14 to 17 years old. Indeed, it is now known that the steep decline antisocial behaviour between ages 7 and 17. A classic finding in the previous studies indicated that about $37 \%$ of both men and women, however, retained low antisocial behaviour through age 48 . 
However, it is postulated that children exhibiting overt behaviour were found to have two times greater risk for covert behaviour as an adolescent and three times greater risk for it in adulthood [113]. The development theories posit that deficiencies in self control or in one's ability to refrain from antisocial behaviour are the root cause of all antisocial activities. Moffitt illustrated that, in the modern society, there is an ever-widening distance between the age of attainment of physical maturity and the age of attainment of adult status (what is referred to as maturity gap) once some of these youths have attained adult status, their antisocial behaviour ceases [79]. In contrast, life course-persistent offenders are known to suffer from neurological and cognitive deficits that, in combination with early family disadvantage and drug use, continue to effect functioning and underpin antisocial behaviour that is maintained into adulthood. According to developmental theory of age, numerous reasons form the link between antisocial behaviour and poor self control. These include: a) individuals with low self control pursue immediate gratification and are oriented on the "now" as opposed to the future, b) Antisocial acts provide easy and or simply gratification of desires.

According to Bowlby's attachment theory, as age, a cognitive growth and continued social experience advance the development and complexity of the internal working models, as the child moves from childhood to adolescence, attachment-related behaviours lose some characteristics typical of the infant-toddler period and take on age-related tendencies. Relationship with peers become influential in the child's emotional well-being which is different from that of parent-child relationships within the family, though the later can influence the peer relationships these adolescents form. These attachment to peers which emerges in adolescence, although parents continue to be attachment figures, play a huge role in directing the emotional development and adjustment of the individual. With adolescents, the role of the parental figures becomes necessary when needed while the adolescent makes excursion into the outside world [114].

\subsection{Implication of the Study}

The findings of this research have many practical implications. First, drug use was found to be a significant determinant of antisocial behaviour. The nascent implication of this finding is that crime in the country may continue to grow even in geometric rate if the rate of consumption/use of drug especially among the youths and more among the adolescence is not check mated. Over the years and worst still now, crime/antisocial acts have always been more linked to drug use. Unfortunately, these youth/adolescents that engage in drug use represent the future leader, society changers, some with sharp innovation brain but all these are turned into almost impossibility by drug use. There is no doubt saying that drug use contributes a lot in the execution of many antisocial activities such like those recorded. More still, when youths dedicate more time to drug use, it makes the overwhelming energy they have to be channeled into different forms of antisocial behaviours other than creativity/innovations [115]. This is true when compared to an average Nigerian youths free from drug use. They record out- 
standing achievements if different fields. Therefore, the finding of this study serves as a clarion call to the entire society, Nigerian Government, leaders of different sectors, Health and educational sectors to rise up and wage war against this ugly act youth drug uses.

The finding of the study has also shown that any form of spirituality without much dedication breeds different forms of antisocial behaviours. A practical implication of this is that without serious dedication to spiritual/religious practices especially.

The finding of the study has also shown that any form of spirituality without much dedication breeds different forms of antisocial behaviours. A practical implication of this is that without serious dedication to spiritual/religious practices especially among the youths, the huge Nigerian religious form will only be in shambles. Nigeria is a very religious country, but this study has confirmed that it is not about going to church or mosque and the religious country, and the like, rather keeping and observing the moral teachings. Thus, the study calls on all Nigerian religious leaders, to teach more about love that goes with morality. More still about spiritual dedication will always breed a near perfect society.

One other interesting finding of this research is that individuals who lacking in intimacy are most likely to exhibit antisocial behaviours. An interesting implication of this is that anti social behaviours is not just about drug use, but that lack of good and support-filled intimacy will lead youths into antisocial behaviours. Past and present researches have continued to show that youths who engaged in antisocial behaviours have their intimacy relations vacuum. They are lacking in family care or close relations/friendship care. However, there is need for our families to rise up to their responsibilities of caring for and providing for their children; for the communities/government at all levels to rise up to their responsibilities of providing basic amenities to its citizens.

Moreover, the finding of this study that youths of younger ages exhibit antisocial behaviours more than youths of older ages. This has relevant implication in our present Nigerian condition. Presently, Nigerian youths are overtaken by show-casing immoral practices, be it through social media, religious chauvinism, drug use, poor parental upbringing, bad government, bad economy etc. all these hugely make younger youths to engage more in antisocial behaviours. This is so as their stage of reasoning lack the ability to weigh positive/negative effects of every of their behaviours; unlike older youths who in some forms have been exposed to the ugly nature of antisocial behaviours. Therefore, the study enjoins all to put more effort in concertizing the younger youths on the roles of drugs, spirituality, and intimacy on antisocial so as to minimize or curtail drug use amount the youths.

\subsection{Limitation of the Study}

Like every scientific study, present study has some limitations. First there was a problem of finance. The fact that there was no sponsorship for the study constituted limitation as wider coverage more than did in the study would have been 
done. This implies that the present only covered the extent that the researcher's finance could achieve. Another limitation is the time consuming nature as witnessed during the course of study. The researcher spent a lot of time reaching out to the participants.

\subsection{Suggestions for Further Research}

Following the limitations highlighted above, the researcher makes the following suggestions for further research. Future researches interested on the same variables as this research on antisocial behaviour, should consider using participants from more than one local Government in Enugu, more areas in South East Zone and better still more regions of the country, while also increasing the number of participants for the study. Furthermore, in testing antisocial behaviour, effort should be made in investigating the moderating or mediating roles of variables like socio-economic status, locality, ethnic groups, peer influence and gender, while the participants of different regions might be involved to check for the determinants of the different dimensions of antisocial behaviour independently.

\section{Conclusions}

This study was carried out to investigate drug use, spirituality, intimacy and age as determinants of antisocial behaviours among youths. Four hundred and sixty eight (468) youths participated in the study. Antisocial behaviours by youths appear to be the symptoms of the social and moral decadence of the Nigeria society in general vis-à-vis other countries of the world. For in the contemporary Nigeria setting, it is however observed that a lot of youth exhibit dishonest behaviour without any fear of apprehension. This is both in rural and urban areas, the streets and residents are no longer safe, no matter how well fortified they may be. Street-smart-boys popularly known as "Area-boys" are found everywhere roaming the streets and residences are no longer safe, no matter how well fortified they may be. Street-smart boys popularly known as "Area-boys" are found everywhere roaming the streets, harassing and extorting money from innocent people; bank robbery, money laundering involvement in theft popularly known as " 419 " kidnapping, car snatching, armed robbery, cultism, assaults, rape, violence, substance abuse, alcoholism, certificate racketing, vandalism, examination malpractices to mention but a few.

As stated in the study, youths are the expected future leaders. However these youths would be found future leaders engage in crime, violence and other delinquent and corrupt behaviour; there can never be peace, progress and sustainable development [5]. As a fight this against menace, this study recommends that efforts should be made to restrict drug use and consumption especially among youths, our spirituality should be more exemplary, dedicated, and moral other than casual. Emotional supports are basic amentias of life should be provided for the youths, to free their minds from antisocial thoughts. Younger youth should be given early orientation on adverse effect of antisocial behaviours. If all these are kept our society will be proud. 


\section{Compliance with Ethical Standards Conflict of Interest}

All authors declare that they have no conflict of interest. All participants filled the consent form to declare their free will to participate in the study. Again, this study was not funded by any person, group or organization.

\section{References}

[1] Department of Statistics (2010) Census of Population 2010 Statistical Release 1: Demographic Characteristics, Education, Language and Religion. Department of Statistics. Ministry of Trade and Industry, Singapore.

[2] World Health Organization (WHO) (2008) World Health Organization Suicide Prevention (SUPRE): Retrieved 2008 from June 20.

http://www.who.int/mental-health/prevention/Suicide Prevention/en/

[3] United Nations General Assembly (2008) General Assembly Adopts Resolution Reaffirming Territorial Integrity of Azerbaijan, Demanding Withdrawal of All Armenian Forces. United Nations.

[4] Dalsgaard, A. and Karen, T. (2008) Youth and the City in the Global South. In Tracking Globalization. Indian University Press, Bloomington.

[5] Asuquo, P.N., Uwe, E.A. and Ekuri, E.E. (2008) Parenting and Responsibility: Holding Parents Accountable for Children's Antisocial Practices. Journal of Human Ecology, 24, 51-57. https://doi.org/10.1080/09709274.2008.11906099

[6] Ifaturoti, T. (1994) Delinquent Sub-Culture and Violence in Nigerian Universities. In: Albert, I.O., et al., Eds., Urban Management and Urban violence in Africa, Vol. 2, IFRA, Ibadan.

[7] Bronfrenbrener, U. (1987) Ecological Systems Theory: In: Vasta, R., Ed., 1989 Six Theorities of Child Development. Revised Formulations of Current Issues Vol. 6, JA/Press, Greenwich, Connecticut.

[8] Azimi, H., Turiman, S. and Ezhar, T. (2000) Youth Life and Thinking Pattern in National Development Faces the Millennium. Kementerian Belia dan, Patrajaya, 57-61.

[9] Scout, W.R. (2008) Institutions and Organizations: Ideas and Interests. 3rd Edition, Sage Publications, Los Angeles.

[10] Webster-Stratton, C. and Reid, M.J. (2008) Strengthening Social and Emotional Competence in Socio-Economically Disadvantaged Young Children: Preschool and Kindergarten School-Based Curricula. In: Brown, W.H., Odom, S.L. and McConnell, S. R, Eds., Social Competence of Young Children: Risk, Disability, and Intervention, Paul H. Brookes Publishing Co., Baltimore, 185-203.

[11] Bloomquist, M. and Schnell, S. (2005) Helping Children with Aggression and Conduct Problems: Best Practices for Intervention. The Guildford Press, New York.

[12] Squires, P. (2008) ASBO Nation: The Criminalization of Nuisance. Policy Press, Bristol. https://doi.org/10.2307/j.ctt9qgt9w

[13] American Psychiatric Association (2013) Diagnostic and Statistical Manual of Mental Disorders. 5th Edition, American Psychiatric Press, Washington, DC. https://doi.org/10.1176/appi.books.9780890425596

[14] The Crime and Disorder Act (1998) UK Public General Acts. http://www.legislation.gov.uk/

[15] World Health Organization (WHO) (1996) Investing in Health Research and Development. Report of the Ad Hoc Committee on Health Research Relating to Future Intervention, Options. WHO, Geneva. 
[16] Widger, T.A. and Costa Jr., P.T. (1995) Personality and Personality Disorders. Journal of Abnormal Psychology, 103, 78-91. https://doi.org/10.1037/0021-843X.103.1.78

[17] Charlebois, P., LeBlanc, M., Gagnon, C., Larvae, S. and Tremblay, R (1993) Age Trends in Early Behavioiural Predictors of Serious Antisocial Behaviours. Journal of Psychopathology and Behavioural Assessment, 15, 23-41. https://doi.org/10.1007/BF00964321

[18] Lynam, D.R. (1996) Early Identification of Chronic Offenders Who Is a Fledgling Psychopath? Psychological Bulletin, 120, 209-234. https://doi.org/10.1037/0033-2909.120.2.209

[19] Million, T., Davis, R., Escover, L. and Meagher, S. (2000) Personality Disorders in Modern Life. Willey, New York.

[20] Kraus, G and Reynolds, D.J. (2001) The “a-b-c's" of the Cluster B's: Identifying, Understanding and Treating Cluster B Personality Disorders. Clinical Psychology Review, 21, 345-373. https://doi.org/10.1016/S0272-7358(99)00052-5

[21] Cleckley, H. (1982) The Mask of Sanity. 7th Edition, C. V. Mosby, St Louis. (Original work published 1941).

[22] Copeland, J., Howard, J., Keogh, T. and Seidler, T (2003) Parents and Correlates of Substance Use among Juvenile Dtainees in New South Wales 1989-1999. Drug and Alcohol Review, 22, 15-20. https://doi.org/10.1080/0959523021000059785

[23] Pudney, S. (2002) The Road to Ruin? Sequences of Initiation into Drug Use and Offending by Young People in Britain. Home Office Research Study 253, Home Office, London.

[24] Schoemaker, D.J. (2000) Theories of Delinquency. An Examination of Explanations of Delinquent Behavioiur. 4th Edition, Oxford University Press, New York.

[25] Fuller, E. (2007) Drug Use, Smoking and Drinking among Young People in England. National Centre for Social Research, National Foundation for Education Research.

[26] Galaif, E., Sussman, S., Newcomb, M.D. and Locke, T.F. (2007) Suicidality, Depression and Alcohol/Drug Use among Adolescents: A Review of Empirical Findings. International Journal of Adolescent Medicine and Health, 19, 27-35. https://doi.org/10.1515/IJAMH.2007.19.1.27

[27] Hussong, A., Curran, P. and Chassin, L. (1998) Pathways of Risk for Accelerated Heavy Alcohol Use among Adolescent Children of Alcoholic Parents. Journal of $A b$ normal Child Psychology, 26, 453-466. https://doi.org/10.1023/A:1022699701996

[28] Velleman, R.D.B., Templeton, L.J. and Copello, A.G. (2005) The Role of Family in Preventing and Intervening with Substance Use and Misuse: A Comprehensive Review of Family Interventions, with a Focus on Young People. Drugs and Alcohol Review, 24, 93-109. https://doi.org/10.1080/09595230500167478

[29] Huizinga, D., Loeber, R. and Thornberry, T. (1995) The Prevention of Serious Delinquency and Violence. In: Howell, J.C., Krisberg, B., Hawkins J.D. and Wilson, J.J., Eds., Sourcebook on Serious, Chronic, \& Violent Offenders, Sage, Thousand Oaks.

[30] Bui, M., Ellickson, P. and Bell, R (2000) Cross-Lagged Relationships among Adolescent Problem Drug Use, Delinquent Behaviour, and Emotional Distress. Journal of Drug Issues, 30, 283-303. https://doi.org/10.1177/002204260003000203

[31] Ford, C.S. (2005) Patterns of Sesrrcrl Behavior. Harper \& Row, New York. (ATG)

[32] Goldstein, P.J. (1989) Drugs and Crime. In: Weiner, N.A. and Wolfgangf, M.E., Eds., Pathways to Criminals Violence, Sage, Newburry Park, 16-48. 
[33] Arrestee Drug Abuse Monitoring (ADAM) Program in the United States, (ICPSR 2994) (1999) Principal Investigator(s): United States Department of Justice. Office of Justice Programs. National Institute of Justice.

[34] Huizinga, D. and Jakob-Chien, C. (1998) Chapter 4: The Contemporaneous Co-Occurrence of Serious and Violent Juvenile Offending and Other Problem Behaviours. In: Leober, R. and Farrington, D.P., Eds., Serious and Violent Juvenile Offenders: Risk Factors and Successful Interventions, Sage Publications, Inc., Thousand Oaks, 47-67. https://doi.org/10.4135/9781452243740.n4

[35] Teplin, L. (2001) Assessing Alcohol, Drug, and Mental Disorders in Juvenile Detainees. U.S. Office of Juvenile Justice and Delinquency Prevention, Washington DC.

[36] Weisner, M., Kim, H.K. and Capaldi, D.M. (2005) Developmental Trajectories of Offending: Validation and Prediction to Young Adult Alcohol Use, Drug Use, and Depressive Symptom. Development and Psychopathology, 17, 251-270. https://doi.org/10.1017/S0954579405050133

[37] Derision, M., Paredes, A., Bascal, S. and Godwin, F. (1998) Psychological and Psychiatric Consequences of Cocaine. In: Tartar, Ed., Handbook of Substance Abuse. Nemobehavioural Pharmacology, Plenuim Press, New York, 161-185.

[38] Miller, D.C. (1991) Handbook of Research Design and Social Measurement. 5th Edition.

[39] Adams, E., Blanken, A., Ferguson, L. and Kopstein, A. (1990) Overview of Selected Drugs Trends. National Institute on Drug Abuse, Rockville.

[40] Elliot, D., Huizinga, D. and Menard, S. (1989) Multiple Problem You: Delinquency, Substance Use and Mental Health Problems. Springer-Verlag, New York. https://doi.org/10.1007/978-1-4613-9637-6

[41] Antonaccio, O., Tittle, C., Botchkovar, E. and Krandidiotis, M. (2010) The Correlates of Crime and Deviance: Additional Evidence. Journal of Research in Crime \& Delinquency, 10, 55-67. https://doi.org/10.1177/0022427810365678

[42] United Nations Office on Drug and Crime (UNODC) (2010) Relatorio mundial sobre drogas WDR. http://www.Unodc.org

[43] Blair, C. and Wright, B. (2001) If You Love Me, Keeping Commandments: A Meta-Analysis of the Effect of Religion on Crime. Journal of Research in Crime \& Delinquency, 38, 3-21. https://doi.org/10.1177/0022427801038001001

[44] Worthington, S. (2011) Testing the Anti-Deprivation Rule: A Response to "Lehman Brothers and the Anti-Deprivation Principles: Current Uncertainties and Proposals for Reform". Capital Markets Law Journal, 6, 450-455. https://doi.org/10.1093/cmlj/kmr034

[45] Mayer, A. (1995) Described Antisocial Behaviour as Repeated Violations of Normative Behaviour Usually Involving Aggression, Vandalism Rule Infraction, Defiance of Adult Authority and Violation of the Social Norms and Norms of Society.

[46] Reach out.com. What Is Spirituality? http://www.reachout.com/

[47] Benson, E. (2003) The Many Faces of Perfectionism: The Need for Perfection Comes in Different Flavors, Each Associated with Its Own Set of Problems, Researchers Say. Monitor Staff, 34, 18.

[48] Ballengar, W. and Rocha, J. (2007) The politics of policies about gangs in Central America. In: Cruse, J.M., Ed., Street Gangs in Central America, UCA Editors, San Salvador, El Salvador, 115-135.

[49] Regnerus, M.D. and Glen, H.E. (2003) Staying on Track in School: Religious Influences in High-and Low-Risk Settings. Journal for the Scientific Study of Religion, 42, 633-649. https://doi.org/10.1046/j.1468-5906.2003.00208.x 
[50] Flores, E. (2009) I Am Somebody, Barrio Pentecostalism and Gendered Acculturation among Chicago Ex-Gang Me Members. Ethnic and Racial Studies, 32, 996-1016. https://doi.org/10.1080/01419870802485507

[51] Marsal, K. (2009) Obstetric Management of Intrauterine Growth Restriction. Best Practice \& Research Clinical Obstetrics \& Gynecology, 23, 857-870. https://doi.org/10.1016/j.bpobgyn.2009.08.011

[52] Morris, E.J. (2012) Respect, Protection, Faith and Love: Major Care Constructs Identified without the Substructure of Selected Urban African American Adolescent Gang Members. Journals of Tran-Cultural Nursing, 23, 262-269. https://doi.org/10.1177/1043659612441014

[53] Catalano, R. and Hawkins, J. (1996) The Social Development Model: A Theory of Antisocial Behaviour. In: Hawkins, J.D., Ed., Delinquency and Crime? Current Theories, Cambridge University Press, New York, 149-197.

[54] Johnson, B., Jang, S., Larson, D. and Deli, S. (2001) Does Adolescent's Religious Commitment Matter? A Reexamination of the Effects of Religiosity on Delinquency. Journal of Research in Crime and Delinquency, 38, 22-44. https://doi.org/10.1177/0022427801038001002

[55] Salas-Wright, C.P., Vaugtin, M.G., Hodge, D.R. and Derron, B.E. (2012) Religiosity Profiles of American Youth in Relation to Substance Use, Violence and Delinquency. Journal of Youth and Adolescence, 41, 1560-1575. https://doi.org/10.1007/s10964-012-9761-Z

[56] Benson, P. and Rochlkepartain, E. (2008) Spiritual Development: A Missing Priority in Youth Development. Spiritual Development, 2008, 13-28. https://doi.org/10.1002/yd.253

[57] King, P.E. and Boyatzis, C.J. (2004) Exploring Adolescent Spiritual and Religious Development, Current and Future Theoretical and Empirical Perspectives. Applied Development Sciences, 8, 2-6. https://doi.org/10.1207/S1532480XADS0801_1

[58] Wrong, S. and Fry, P.S. (1998) The Development of Personal Meaning and Wisdom in Adolescence: Re-Examination of Moderating and Consolidating Factors and Influences. In: Wrong, P.T.P. and Fry, A.S., Eds., The Human Quest for Meaning. A Handbook of Psychological Research and Clinical Application, Erlbaum, Mahwah, 91-110.

[59] Weeks, G.R. and Treat, S. (2001) Couples in Treatment: Techniques and Approaches for Effective Practice. 2nd Edition, Brunner/Routledge, Philadelphia.

[60] Butler, M.H., Davis, S.D. and Seedall, R.B. (2008) Common Pitfalls of Beginning Therapies utilizing Enactments. Journal of Marital and Family Therapy, 34, 329-352. https://doi.org/10.1111/j.1752-0606.2008.00076.x

[61] Fife, S.T., Weeks, G.R. and Gambescia, N. (2008) Treating Infidelity: An Integrative approach. Family Journal of Counseling \& Therapy for Couples and Families, 8, 112-140.

[62] Popovic, M. (2005) Intimacy and Its Relevance in Human Functioning. Sexual and Relationship Therapy, 20, 31-49. https://doi.org/10.1080/14681990412331323992

[63] Mirgain, S.A. and Cordova, J.V. (2007) Emotion Skills and Marital Health: The Association between Observed and Self-Reported Emotion Skills, Intimacy, and Marital Satisfaction. Journal of Social and Clinical Psychology, 26, 983-1009. https://doi.org/10.1521/jscp.2007.26.9.983

[64] Downey, D.B. (2001) Number of Siblings and Intellectual Development: The Resource dilution Explanation. American Psychologist, 56, 497-504. https://doi.org/10.1037/0003-066X.56.6-7.497 
[65] Selman, R.L. (1990) Fostering Intimacy and Autonomy. In: Damon, W., Ed., Child Development Today and Tomorrow, Jossey-Bass, San Francisco.

[66] Furman, W. and Bierman, K.L. (1983) Developmental Changes in Young Children's Conceptions of Friendship. Child Development, 54, 549-556. https://doi.org/10.2307/1130041

[67] Oden, S., Hertzberger, S.D., Mangaine, P.L. and Wheeler, V.A. (1984) Children's Peer-Relationship: An Examination of Social Processes. In: Masters, J.C. and Yarkin-Levin, K., Eds., Boundary Areas in Soda's, and Developmental Psychology, Academic Press, New York.

[68] Reiss, H.T. and Farrington, D.P. (1988) Intimacy as an Interpersonal Process. In: Duck, S., Ed., Handbook of Personal Relationships: Theory, Relationships, and Intervention, Wiley, Chichester.

[69] Kelley, H., Berschied, E., Christensen, A., Harvey, J., Huston, T., Levinger, G, McClintock, E., Peplau, L. and Peterson, D. (1983) Close Relationships. Freeman, New York.

[70] Laursen, B. (1993) Close Friendships in Adolescence. Jossey-Bass, San Francisco.

[71] Erikson, E.H. (1963) Childhood and Society. Norton, New York.

[72] Mosier, W. (2006) Intimacy. The Key to a Healthy Relationship. Annals of the American Psychotherapy Association, 9, 34-35.

[73] Grotevant, H.D. and Cooper, C.R. (1985) Patterns of Interactions in Family Relationships and the Development of Identity Exploration in Adolescence. Child Development, 56, 415-428. https://doi.org/10.2307/1129730

[74] Reis, H.T. and Shaver, P. (1988) Intimacy as an Interpersonal Process. In: Duck, S., Ed., Handbook of Personal Relationships. Theory, Relationships and intervention, Wiley, Chichester.

[75] Martin, J.L. and Ashby, J.S. (2004) Perfectionism and Fear of Intimacy. The Implication for Relationships. The Family Journal, 12, 368-374.

https://doi.org/10.1177/1066480704267279

[76] Shulman, S. (1993) Early and Middle Adolescent Dose Friendship: Typology and Friendship Reasoning. In: Laursen, B., Ed., Close Friendships in Adolescence, Jossey-Bass, San Francisco.

[77] Shulman, S., Elicker, J. and Sroufe, L.A. (1994) Stages of Friendship Growth in Preadolescence as Related to Attachment History. Journal Social Personality Relationship, 11, 341-361. https://doi.org/10.1177/0265407594113002

[78] Bernice, L.N. and Dail, A.N. (1987) The Changing Meanings of Age. (Life Flow) Psychology Today, 29, 22-28.

[79] Moffitt, T.E. (1993) Adolescence-Limited and Life-Course-Persistent Antisocial Behavior: A Developmental Taxonomy. Psychological Review, 100, 674-701. https://doi.org/10.1037/0033-295X.100.4.674

[80] Immanuel, E.U. (2015) Measuring Antisocial Bahaviour. Unpublished Manuscript. Institution, Escalation and Desistance in Juvenile Offending and Their Correlates Career Development for Exceptional Individuals, 17, 115-124.

[81] Center for Substance Abuse Treatment (1994) Simple Screening Instrument for Outreach for Alcohol and Other Drug Abuse and Infectious Diseases (Treatment Improvement Protocol (TIP) Series No.11). U.S. Department of Health and Human Services, Rockville.

[82] Underwood, L.G. (2011) The Daily Spiritual Experience Scale: Overview and Results. Religions, 2, 29-50. https://doi.org/10.3390/rel2010029 
[83] Onyeizugbo, E.U. (2011) A Scale for Assessing Emotional Intimacy. Unpublished Manuscript.

[84] Peters, R.H., Greenbaum, P.E, Steinberg, M.L., Carter, C.R., Ortiz, M.M. and Valle, S.K. (2000) Effectiveness of Screening Instruments in Detecting Substance Use Disorders among Prisoners. Journal of Substance Abuse Treatment, 18, 349-358. https://doi.org/10.1016/S0740-5472(99)00081-1

[85] Underwood, L.G. and Teresi, J.A. (2002) The Daily Spiritual Experience Scale: Development, Theoretical Description, Reliability, Exploratory Factor Analysis, and Preliminary Construct Validity Using Health Related Data. Annuals of Behavioural Medicine, 24, 22-23. https://doi.org/10.1207/S15324796ABM2401_04

[86] Nandi, F.L., Cunha, S.M., Bizarro, L. and Dell'Aglio, D.D. (2012) Drug Use and Antisocial Behaviour among Youth Attending Public Schools in Brazil. Trends in Psychiatry and Psychotherapy, 34, 80-86. https://doi.org/10.1590/S2237-60892012000200006

[87] Green, R. and Ross, A. (2010) Young People's Alcohol Consumption and Its Relationship to Other Outcomes and Behavioir.

[88] World Health Organization (2010) Contains WHO's Annual Compilation of Data from Its 193 Members States, and Includes a Summary of Progress towards the Health-Related Millennium Development Goals and Targets. World Health Organization, Geneva.

[89] Spunt, B., Goldstein, P. and Brownstein, H.H. (1994) Alcohol and Homicide: Interviews with Prison Inmates. Journal of Drugs Issues, 24, 143-163. https://doi.org/10.1177/002204269402400108

[90] Akers, R. and Sellers, C. (2004) Criminological Theories: Introduction, Evaluation, and Application. 4th Edition, Roxbury Publishing, Los Angeles.

[91] Jessor, R. (1987) Problems-Behaviour Theory, Psychosocial Development, and Adolescent Problem Drinking. British Journal of Addiction, 82, 331-342. https://doi.org/10.1111/j.1360-0443.1987.tb01490.x

[92] Sinha, J.W., Cnaan, R.A. and Gelles, R.J. (2007) Adolesent Risk Behaviours and Religion: Findings from a National Study. Journal of Adolescent, 30, 231-249. https://doi.org/10.1016/j.adolescence.2006.02.005

[93] Fowler, J.W. (1981) Stages of Faith. Harper and Row, New York.

[94] Lewis, M.M. (2001) Spiritual, Counseling, and Elderly: An Introduction to the Spiritual life Review. Journal of Adult Development, 8, 231-240. https://doi.org/10.1023/A:1011390528828

[95] Fry, P.S. (1998) The Development of Personal Meaning and Wisdom in Adolescence: A Reexamination of Moderating and Consolidating Factors and Influences. In: Wong, P.T.P and Fry, P.S., Eds., The Human Quest for Meaning. A Handbook of Psychological Research and Clinical Applications, Erlbaum, Mahwah, 91-110.

[96] Booth, M. (1998); Opium: A History. Martin's Press, New York.

[97] Evans, N. (1995) A Grammar of Kayarddild. With Historical-Comparative Notes on Tangkic. Mouton Grammar Library, 15, Mouton de Gruyter, Berlin. https://doi.org/10.1515/9783110873733

[98] Pawlak, R. and DeFronzo, J. (1993) Social Bonds, Early Trauma and Smoking: Evidence of the Group-Specific Relevance of Control-Theory. Journal of Drug Education, 23, 201-214. https://doi.org/10.2190/CFU6-BXBG-HQ4M-20T8

[99] Cochran, J. (1993) The Variable Effects of Religiosity and Denomination on Adolescent Selfreported Alcohol Use by Beverage Type. Journal of Drug Issues, 23, 479-491. https://doi.org/10.1177/002204269302300308 
[100] Benda, B.B. and Crown, R.F. (2001) Are the Effects of Religion on Crime Mediated, Moderated, Misrepresented, by Inappropriate Measure? Journal of Social Service Research, 27, 57-86. https://doi.org/10.1300/J079v27n03_04

[101] Rachael, D.R., Laura, J.D. and Mikayla, C.U. (2015) Friendship, Negative Peer Experiences, and Daily Positive and Negative Mood. Social Development, 24, 833-851. https://doi.org/10.1111/sode.12123

[102] Knack, J.M., Jacquot, C., Jensen-Campbell, L.A. and Malcolm, K.T. (2013) Importance of Having Agreeable Friends in Adolescence (Especially When You Are Not). Journal of Applied Social Psychology, 43, 2401-2413. https://doi.org/10.1111/jasp.12188

[103] You, J.-I. and Bellmore, A. (2011) Relational Peer Victimization and Psychosocial adjustment: The Mediating Role of Best Friendship Qualities. Personal Relationships, 19, 340-353. https://doi.org/10.1111/j.1475-6811.2011.01365.x

[104] Sally, F. and Kay, B. (2013) The Role of Perceived Friendship Self-Efficacy as a Protective Factor against the Negative Effects of Social Victimization. Social Development, 23, 41-60. https://doi.org/10.1111/sode.12032

[105] Claes, M.E. (1992) Friendship and Personal Adjustment during Adolescence. Journal of Adolescence, 15, 39-55. https://doi.org/10.1016/0140-1971(92)90064-C

[106] Bowlby, J. (1969) Attachment and Loss. Attachment, Vol. 1, Basic Books, New York.

[107] Prior, V. and Glaser, D. (2006) Understanding Attachment and Attachment Disorders: Theory, Evidence and Practice. Jessica Kingsley Publishers, London.

[108] Donker, A.G., Smeenk, W.H., van der Laan, P. and Verhulst, F.C. (2003) Individual Stability of Antisocial Behavior from Childhood to Adulthood: Testing the Stability Postulate of Moffit's Developmental Theory. Criminology, 41, 593-609. https://doi.org/10.1111/j.1745-9125.2003.tb00998.x

[109] Blumstein, A. and Cohen, J. (1987) Characterizing Criminal Careers. Science, 237, 985-991. https://doi.org/10.1126/science.237.4818.985

[110] Farrington, D.P. (1986) Age and Crime. Crime and Justice, 7, 189-250. https://doi.org/10.1086/449114

[111] Loeber, R., Stouthamer-Loeber, M., Van Kammen, W.B. and Farrington, D.P. (1989) Development of a New Measure of Self-Reported Antisocial Behavior for Young Children: Prevalence and Reliability. In: Klein, M.W. Ed., Cross-National Research in Self-Reported Crime and Delinquency, Kluwer, Dordrecht, Netherlands, 203-225.

[112] Wong, Y.J., Rew, L. and Slaikeu, K.D. (2006) A Systematic Review of Recent Research on Adolescent Religiosity/Spirituality and Mental Health. Issues in Mental Health Nursing, 27, 161-183. https://doi.org/10.1080/01612840500436941

[113] Huesmann, L.R., Dubow, E.F. and Boxer, P. (2003) Theoretical and Methodological Considerations in Cross-Generational Research on Parenting and Child Aggressive Behavior. Journal of Abnormal Child Psychology, 31, 185-192. https://doi.org/10.1023/A:1022526325204

[114] Bowlby, J. (1988) A Secure Base: Parent-Child Attachment and Healthy Human Development. Tavistock Professional Book. Routledge, London.

[115] Adeoye, M.N. and Muhammed, A.Y. (2005) Terrorism in Nigeria's Fourth Republic: Implications for Sustainable Democracy and Development. The National Conference on Democracy and Development, Faculty of Business and Social Sciences, University of Ilorin, Ilorin. 